\title{
Effect of ovine trophoblast protein-1, oestrogen and progesterone on oxytocin-induced phosphatidylinositol turnover in endometrium of sheep*
}

\author{
J. L. Vallet and F. W. Bazer \\ Department of Animal Science, University of Florida, Gainesville, FL 32611, USA
}

\begin{abstract}
Summary. In Exp. 1, endometrium was collected from Day-15 cyclic ewes and effects of oTP-1, oxytocin and oTP-1 + oxytocin, in various temporal relationships, on phosphatidylinositol (PI) turnover were determined. Co-treatment of endometrium with oTP-1 and oxytocin inhibited stimulatory effects of oxytocin, while treatment with oTP-1 before and during oxytocin administration had no effect. Turnover of PI was unaffected by oTP-1 alone. In Exp. 2, ovariectomized ewes were treated with progesterone $(50 \mathrm{mg} / \mathrm{day})$ for 10 days and then oestrogen $(100 \mu \mathrm{g} / \mathrm{day})$ for 2 days and endometrium was collected. Oxytocin stimulated PI turnover in endometrium, but oTP-1 had no effect alone or in combination with oxytocin. In Exp. 3, ovariectomized ewes were treated with corn oil $(1 \mathrm{ml} /$ day $)$, oestrogen $(50 \mu \mathrm{g} /$ day $)$, progesterone $(50 \mathrm{mg} /$ day $)$ or progesterone + oestrogen for 10 days and endometrium was collected. Oxytocin stimulated PI turnover only in ewes that received progesterone. OTP-1 alone had no effect on PI turnover, while co-treatment of endometrium with oxytocin and oTP-1 stimulated PI turnover in ewes treated with progesterone, but not progesterone and oestrogen. Pretreatment of endometrium with oTP-1 stimulated PI turnover when ewes were treated with progesterone or progesterone + oestrogen. Pretreatment of endometrium with oxytocin and then treatment with oTP-1 inhibited PI turnover compared to treatment with oxytocin alone. In Exp. 4, ovariectomized ewes were treated as in Exp. 2. Catheters were placed into the uterine horns and ewes received oTP-1 into one horn and serum into the other twice daily on Days 10-12 of steroid treatment. Endometrium collected on Day 13 was used to measure PI turnover and received either no treatment or oxytocin. Oxytocin stimulated PI turnover in endometrium of these ewes and in-vivo treatment of the ewes with oTP-1 had no effect on PI turnover. These results indicate that antiluteolytic effects of oTP-1 are not mediated by inhibiting effects of oxytocin on phosphatidylinositol turnover if oxytocin receptors are present and that uterine responsiveness to oxytocin is progesterone dependent.
\end{abstract}

Keywords: sheep; conceptus; ovine trophoblast protein-1; phosphatidylinositol turnover; oxytocin

\section{Introduction}

A protein, ovine trophoblast protein one (oTP-1) is secreted between Days 12 and 22 of pregnancy (Godkin et al., 1982) and inhibits luteolysis (Vallet et al., 1988). The mechanism by which oTP-1 inhibits luteolysis is not understood; however, antiluteolytic effects due to pregnancy, total conceptus secretory proteins, and purified oTP-1 are mediated by inhibition of uterine production of luteolytic pulses of prostaglandin (PG) F-2 $\alpha$ (PGF), the luteolysin in sheep (Fincher et al., 1986; Vallet et al., 1988).

\footnotetext{
*Reprint requests to: F. W. Bazer.
} 
McCracken (1980) proposed that release of PGF during luteolysis is mediated by oxytocin. This hypothesis is supported by results which indicated that: (1) oxytocin stimulates PGF release from the uterus (Roberts et al., 1975); (2) interoestrous intervals in sheep are extended after immunization of ewes against oxytocin (Sheldrick et al., 1980); and (3) 97\% of all episodic pulses of uterine PGF released during luteolysis are coincident with peaks of oxytocin in plasma (Hooper et al., 1987). Infusion of purified oTP-1 or total conceptus secretory proteins into the uterine horns of nonpregnant ewes inhibits oestradiol-induced and oxytocin-induced secretion of PGF by the uterus (Fincher et al., 1986; Vallet et al., 1988).

Flint et al. (1986) reported that treatment of endometrial slices with oxytocin in vitro increased phosphatidylinositol (PI) turnover, suggesting that oxytocin mediates its effect by stimulating the phosphatidylinositol-protein kinases C second messenger system (Berridge, 1987). Effects of oTP-1 on PI turnover have not been studied in detail. However, oTP-1 decreases cyclic AMP and has no effect on cyclic GMP in sheep endometrium (Vallet et al., 1987).

This study determined whether: (1) oTP-1 stimulates or inhibits endometrial PI turnover alone and in conjunction with oxytocin; (2) steroid hormone treatment influences effects of oTP-1 and oxytocin on endometrial PI turnover; and (3) the refractory period which occurs after oxytocin stimulation of endometrium (Flint $\&$ Sheldrick, 1986) is caused by down-regulation of PI turnover.

\section{Materials and Methods}

Experiment 1. Endometrium was collected from 5 Day- 15 cyclic ewes, cut into small (approximately $2 \mathrm{~mm}$ ) pieces and $100 \mathrm{mg}$ were placed into each of eight $20-\mathrm{ml}$ scintillation vials. The endometrium included caruncular and intercaruncular tissue since both have receptors for oxytocin (Flint \& Sheldrick, 1986). The oTP-1 used was collected and purified using the method of Vallet et al. (1988).

Table 1. Experimental protocol to determine effects of oTP-1 and oxytocin on phosphatidylinositol turnover in endometrium of sheep in vitro

\begin{tabular}{lll}
\hline & \multicolumn{2}{c}{ Treatment period (min) } \\
\cline { 2 - 3 } In-vitro & $0-160$ & \multicolumn{1}{c}{$160-180$} \\
\hline None & None & None \\
oTP-1 & None & oTP-1 \\
Oxytocin & None & Oxytocin \\
oTP-1 + oxytocin & None & oTP-1 + oxytocin \\
oTP-1 & oTP-1 & oTP-1 \\
Oxytocin & Oxytocin & Oxytocin \\
oTP-1 + oxytocin & oTP-1 & oTP-1 + oxytocin \\
Oxytocin + oTP-1 & Oxytocin & Oxytocin + oTP-1 \\
\hline
\end{tabular}

Endometrium was incubated with one of the respective longterm treatments from 0 to $120 \mathrm{~min}$, radiolabelled with $\left[{ }^{3} \mathrm{H}\right]$ inositol from 120 to $150 \mathrm{~min}$, incubated with $\mathrm{LiCl}$ from 150 to $160 \mathrm{~min}$ to inhibit inositol monophosphatase and subjected to short-term treatments from 160 to $180 \mathrm{~min}$ before the incubations were terminated. See text for details of incubation procedures.

Phosphatidylinositol turnover in endometrium was determined by the method of Flint et al. (1986). The experimental protocol to determine effects of oTP-1 and oxytocin on phosphatidylinositol in vitro is outlined in Table 1 . Briefly, Krebs'-Ringer solution with $10 \mathrm{~mm}$-glucose and $10 \mu \mathrm{M}$-inositol $(1 \mathrm{ml})$ was placed into each vial along with $10 \mu \mathrm{Ci}\left[{ }^{3} \mathrm{H}\right]$ inositol. Two of the vials also received $5 \mu \mathrm{g} \mathrm{oTP}-1 / \mathrm{ml}$ and two received $10^{-7} \mathrm{M}$-oxytocin. Cultures were gassed with $95 \% \mathrm{O}_{2}: 5 \% \mathrm{CO}_{2}$ and the scintillation vials were closed and placed into a shaking water bath and incubated at $37^{\circ} \mathrm{C}$ for $2 \mathrm{~h}$. Medium was removed and replaced with identical medium lacking $\left[{ }^{3} \mathrm{H}\right]$ inositol. Cultures were regassed and incubated a further $30 \mathrm{~min}$. Medium was then changed to medium containing $10 \mathrm{mM}-\mathrm{LiCl}$ to inhibit inositol monophosphatase (Berridge et al., 1982). Vials were regassed and incubated for $10 \mathrm{~min}$. At this time, the 4 
vials which received no oTP-1 or oxytocin received either no treatment, $5 \mu \mathrm{g}$ oTP- $1 / \mathrm{ml}$ (short-term oTP-1), $10^{-7} \mathrm{M}$-oxytocin (short-term oxytocin), or oTP-1 + oxytocin (short-term oTP-1 + short-term oxytocin). The two vials which received oTP-1 received either continuous oTP-1 (long-term oTP-1) or continuous oTP- $1+10^{7} \mathrm{M}-$ oxytocin (iong-term oTP-1 + short-term oxytocin). The two vials which received oxytocin received either continued oxytocin (long-term oxytocin) or continued oxytocin and $5 \mu \mathrm{g}$ oTP-1/ml (long-term oxytocin + short-term oTP-1). Vials were incubated for a further $20 \mathrm{~min}$ before incubations were stopped by aspirating the medium and adding $1 \mathrm{ml}$ ice-cold $15 \%$ trichloroacetic acid (TCA). Tissue was left on ice for at least $15 \mathrm{~min}$ and then the TCA was collected. The TCA was removed from each sample by diethyl ether extraction (water saturated, $\times 5$ ). Samples were neutralized by adding one drop $0.5 \mathrm{M}-\mathrm{Tris}-\mathrm{HCl}, \mathrm{pH} 8$ to each sample. Samples were chromatographed using Dowex-1 as described by Flint et al. (1986). For each sample, the inositol, glycerophosphoinositol, inositol mono-, bis- and trisphosphate fractions were collected and an aliquant $(5 \mathrm{ml})$ of each was subjected to scintillation counting. Disintegrations per minute (d.p.m.) resulting from the three inositol phosphate fractions were combined and treatment effects were expressed on the basis of total inositol phosphates in each sample.

Experiment 2 . Three ewes, ovariectomized for more than 30 days, were given, intramuscularly (i.m.), $50 \mathrm{mg}$ progesterone per day in $1 \mathrm{ml}$ corn oil for 10 days and then $100 \mu \mathrm{g}$ oestradiol- $17 \beta$ per day in $2 \mathrm{ml}$ corn oil for 2 days since this hormonal regimen increases endometrial responsiveness to oxytocin stimulation of PI turnover in sheep (Hixon \& Flint, 1987). Endometrium was collected on Day 13, cultured as described in Exp. 1 and PI turnover determined as described in Exp. 1.

Experiment 3. Twelve ewes, ovariectomized for more than 30 days, were allocated to a treatment group: (1) $1 \mathrm{ml}$ corn oil per day; (2) $50 \mathrm{mg}$ progesterone per day in $1 \mathrm{ml}$ corn oil; (3) $50 \mu \mathrm{g}$ oestradiol-17 3 (i.m.) per day in I ml corn oil; or (4) $50 \mathrm{mg}$ progesterone and $50 \mu \mathrm{g}$ oestradiol- $17 \beta$ per day for 10 days. Endometrium was collected from each ewe, cultured and PI turnover measured as described in Exp. 1 to determine whether oestradiol and progesterone modified effects of oxytocin and oTP-1 in vitro.

Experiment 4. This experiment determined whether long-term in-vivo treatment of endometrium with oTP-1 inhibited PI turnover induced by oxytocin. Three ewes, ovariectomized for more than 30 days, were treated with progesterone and oestradiol-17 $\beta$ as described in Exp. 2 and were fitted with uterine catheters (V6 tubing, Bolab, Lake Havasu City, AZ, USA), as described by Vallet $e t$ al. (1988), on Day 8 after initiation of steroid treatment. Each uterine horn was ligated with a double ligature at a point above the internal bifurcation of the two horns, thus separating them. On Days 10,11 and 12, one uterine horn of each ewe was infused twice daily with $30 \mu \mathrm{g}$ purified oTP-1 plus $1470 \mu \mathrm{g}$ serum proteins from a Day 16 pregnant sheep while the other uterine horn received $1500 \mu \mathrm{g}$ serum proteins. Infusions were in $2 \mathrm{ml} 0.9 \%(\mathrm{w} / \mathrm{v}) \mathrm{NaCl}$ and were followed by $1 \mathrm{ml} 0.9 \% \mathrm{NaCl}$ to clear the catheter. All infusions contained $1000 \mathrm{U}$ ampicillin to prevent infection. Endometrium was collected from these ewes on Day 13 and $100 \mathrm{mg}$ were placed into each of two vials and cultured as described in Exp. 1. For the last $20 \mathrm{~min}$ of the incubation, one vial received no treatment, while the other received $10^{-7} \mathrm{M}$-oxytocin. Incubations were stopped and PI turnover measured as described in Exp. 1.

Statistical analysis. Data from all experiments were analysed using the Statistical Analysis System (SAS Institute, SAS Circle, Cary, NC, USA). Data from Exp. 1 were analysed using a model which included effects of sheep and treatment. For all experiments, results for individual inositol phosphates were similar and so they were combined and the data were analysed as total inositol phosphate produced. Data from incubations treated with long-term oxytocin were analysed separately because variances in these treatment groups were greater than for other treatment groups. Differences among treatment means were examined by orthogonal contrasts for each experiment. Data from Exp. 2 were analysed using a model which included effects of sheep and treatment. Data from Exp. 3 were analysed using a model which included effects of steroid, ewe within steroid treatment group, treatment in vitro (oTP-1 or oxytocin) and interactions. Data from Exp. 4 were analysed using a model which included effects of protein infusion (serum or oTP-1), oxytocin treatment, ewe, and the interaction between protein infusion and oxytocin treatment.

\section{Results}

\section{Experiment 1}

Least squares means for total inositol phosphate in endometrium from ewes in this experiment are presented in Fig. 1. Means for untreated, short-term oTP-1, short-term oTP-1 + short-term oxytocin and long-term oTP-1 groups were not different. Means for the short-term oxytocin and long-term oTP-1 + short-term oxytocin treatment groups were also not different. However, the latter treatment resulted in greater production of inositol phosphates compared to the former treatment groups $(P<0.05)$. Short-term oxytocin treatment resulted in less PI turnover by endometrium than long-term oxytocin treatment $(P<0.05)$. Inositol phosphate production was not different for the long-term oxytocin versus the long-term oxytocin + short-term oTP-1 treatment groups. 


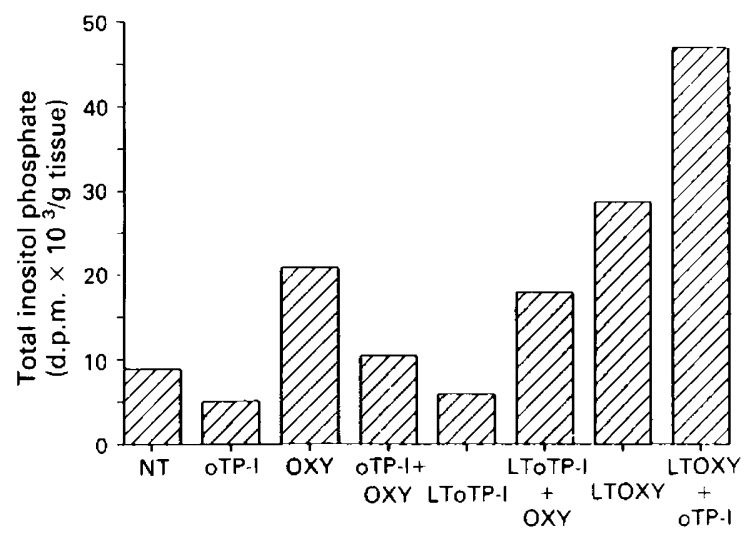

Fig. 1. Least squares means for total inositol phosphate produced by endometrium collected from cyclic ewes in Exp. 1. Treatments were no treatment (NT), short-term oTP-1 (oTP-1), short-term oxytocin (OXY), short-term oTP-1 + short-term oxytocin (oTP-1 + OXY), longterm oTP-1 (LToTP-1), long-term oTP-1 + short-term oxytocin (LToTP-1 + OXY), longterm oxytocin (LTOXY) and long-term oxytocin + short-term oTP-1 (LTOXY + oTP-1). Standard error of the means was 5179 d.p.m./g for the first 6 treatment groups and 9126 d.p.m./ $\mathrm{g}$ for the last 2 treatment groups. Means for NT, oTP-1, oTP-1 + OXY and LToTP-1 treatment groups were not different. The OXY and LToTP-1 + OXY treatment groups were not different. The differences between the combination of the former four treatments versus the latter two treatments was different $(P<0.05)$. The LTOXY and LTOXY + oTP-1 groups were not different. Number of observations for each mean was 5 .

\section{Experiment 2}

Least squares means for total PI turnover in endometrium are illustrated in Fig. 2. Inositol phosphate production was increased $(P<0.01)$ by short-term treatment with oxytocin, but was not different between short-term and long-term oxytocin treatment groups. Neither short- nor long-term treatment of endometrium with oTP-1 had an effect on either basal or oxytocin-induced PI turnover.

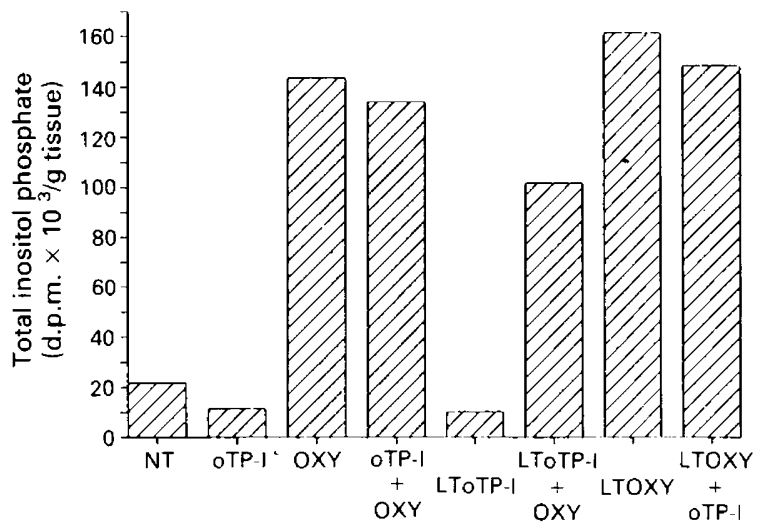

Fig. 2. Least squares means for total inositol phosphates in endometrium from ovariectomized ewes treated for 10 days with progesterone $(50 \mathrm{mg} / \mathrm{day})$ and for 2 days with oestradiol $(100 \mu \mathrm{g} /$ day) in Exp. 2. Treatments were the same as for Fig. 1. Standard error of the means was 18231 d.p.m./g. Both short-(OXY) and long-term oxytocin (LTOXY) treatment stimulated inositol phosphate production $(P<0 \cdot 01)$. Neither short- (oTP-1) or long-term oTP-1 (LToTP-1) treatment had effects on basal or oxytocin-stimulated inositol phosphate production. Number of observations for each treatment group was three. 


\section{Experiment 3}

Least squares means for inositol phosphate produced by endometrium are shown in Fig. 3. No differences among the 8 treatment groups were detected when endometrium from ewes treated with corn oil or oestradiol-17 $\beta$ was used. For progesterone-treated ewes, short-term oTP-1 and oxytocin treatment had no effect on PI turnover; however, short-term oTP-1 + short-term oxytocin was stimulatory to PI turnover $(P=0.05)$. This effect was not detected for ewes treated with progesterone and oestradiol-17 $\beta$. For both progesterone and progesterone + oestradiol-17 $\beta$ treatment groups, long-term oxytocin stimulated inositol phosphate production $(P<0.01)$, but addition of short-term oTP-1 treatment inhibited this response for progesterone-treated $(P<0.01)$ and progesterone + oestradiol-17 $\beta$ treated $(P<0.05)$ ewes. Long-term oTP-1 treatment enhanced PI turnover induced by short-term oxytocin treatment of endometrium from progesterone$(P=0.05)$ and progesterone + oestradiol-17 $\beta(P<0.1)$ treated ewes.

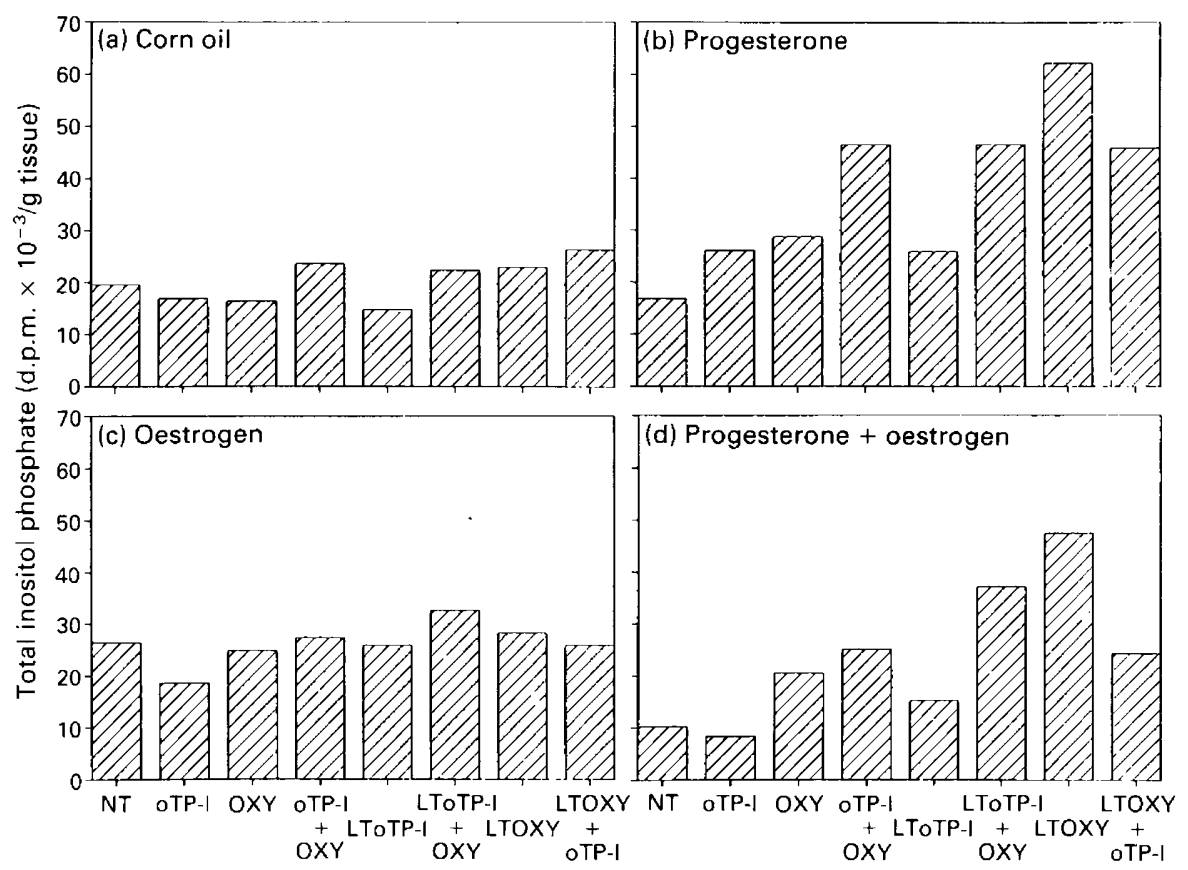

Fig. 3. Least squares means for total inositol phosphate production by endometrium from ovariectomized ewes treated with (a) corn oil, (b) $50 \mathrm{mg}$ progesterone/day, (c) $50 \mu \mathrm{g}$ oestradiol/ day and (d) $50 \mathrm{mg}$ progesterone/day and $50 \mu \mathrm{g}$ oestradiol/day for 10 days (Exp. 3). Treatments are as described in Fig. 1. No effect of treatments was detected for ewes receiving corn oil or oestradiol. For progesterone-treated ewes, neither short-term oTP-1 (oTP-1) or short-term oxytocin (OXY) treatment affected inositol phosphate production. Treatment with short-term oTP-1 + short term OXY (oTP-1 + OXY) stimulated inositol phosphate production $(P=$ $0 \cdot 05)$. Long-term oxytocin (LTOXY) treatment stimulated inositol phosphate production $(P<0.01)$ which was inhibited by addition of short-term oTP-1 (LTOXY + oTP-1, $P<0 \cdot 1)$. For progesterone + oestradiol-treated ewes, short-term oTP-1 (oTP-1) or oxytocin (OXY) or the combination of the two (oTP-1 + OXY) did not affect inositol phosphate production. Long-term oTP-1 (LToTP-1) treatment also had no effect on inositol phosphate production. The combination of long-term oTP-1 + short-term oxytocin (LToTP-1 + OXY) stimulated phosphatidylinositol turnover $(P<0 \cdot 1)$. Long-term oxytocin (LTOXY) treatment stimulated inositol phosphate production $(P<0.01)$ which short-term oTP-1 (oTP-1) treatment inhibited $(P<0 \cdot 1)$. Standard error of the means was 6295 d.p.m./g. Number of observations per treatment groups was 3 . 


\section{Experiment 4}

Least squares means for inositol phosphates produced by endometrium from uterine horns treated with either oTP-1 or serum were 20200 and 18250 d.p.m./g tissue, respectively, for untreated endometrium. Means for oxytocin-treated endometrium were 103000 and 101950 d.p.m./g tissue, respectively. Oxytocin stimulated inositol phosphate production $(P<0.01)$, but effects of oTP-1 alone or the interaction between oTP-1 and oxytocin were not significant.

\section{Discussion}

Results from the present study indicate, for the first time, that oTP-1 alone does not stimulate PI turnover in endometrium. Results from Exp. 1 with untreated cyclic ewes indicated that oTP-1 can inhibit oxytocin-induced PI turnover only when administered at the same time as oxytocin. However, when oTP-1 was given before oxytocin administration, a treatment likely to be similar to temporal relationships between the two proteins in vivo, an inhibitory effect of oTP-1 was not detected. Neither were inhibitory effects of oTP-1 detected when oxytocin was given before oTP-1. Since the more physiologically relevant treatment schedule, i.e. long-term oTP-1 + short-term oxytocin, did not result in inhibition of oxytocin-induced PI turnover, it is concluded that oTP-1 does not inhibit luteolysis by inhibiting oxytocin-induced PI turnover.

Results from Exps 2 and 4 indicated that oTP-1 does not affect PI turnover in endometrium from ovariectomized ewes treated with progesterone and then oestradiol. However, effects of oTP-1 on PI turnover in ovariectomized ewes were progesterone dependent as shown in Exp. 3. Secretion of PGF by endometrium from ovariectomized ewes is also progesterone dependent (Homanics \& Silvia, 1988). These results are consistent since, in Exps 2 and 4, effects of progesterone would have been minimal or absent when the tissue was collected. However, effects of oTP-1 on PI turnover are seemingly inconsistent with its role as an antiluteolytic agent. Administration of oTP-1 either concurrently with or before oxytocin stimulated PI turnover while administration of oTP-1 after oxytocin treatment inhibited PI turnover. However, the latter temporal sequence would not be expected in vivo. Comparison of results from the 4 experiments indicates that effects of oTP-1 differ between ovariectomized steroid-treated ewes and Day 15 cyclic ewes. This indicates that the steroid hormonal milieu of the ewe has an effect on interactions between oTP-1 and oxytocin. Endometrium from ovariectomized steroid-treated ewes did not respond in the same way as that from cyclic ewes. Several explanations are possible. First, steroid treatments may not adequately reproduce temporal patterns of steroid secretion occurring in vivo. Second, establishment of pregnancy in ovariectomized ewes requires prior progesterone treatment before simulation of an oestrous cycle (Miller et al., 1977). Responses of the uterus to oTP-I may require a similar treatment regimen.

Results from Exp. 3 support previous reports (Roberts et al., 1975, 1976) that progesterone treatment for 10 days increases both uterine PGF secretion and oxytocin receptors. This supports the concept that secretion of PGF by the uterus requires oxytocin stimulation of PI turnover.

Results from the present study do not support the concept that the refractory period caused by oxytocin administration (Flint \& Sheldrick, 1985; Sheldrick \& Flint, 1986) results from a decrease in PI turnover, since endometrium treated with oxytocin for only $20 \mathrm{~min}$ produced either equivalent or greater amounts of inositol phosphates compared to endometrium treated for $3 \mathrm{~h}$.

These results also suggest that oTP-1 has no direct effect on either the oxytocin receptor or the oestrogen receptor. Lack of a direct effect of oTP-1 on the oxytocin receptor is suggested by the fact that oTP-1 failed to exert a consistent effect on PI turnover in the 4 experiments. Lack of a direct effect on the oestrogen receptor is suggested by the fact that after progesterone treatment for 10 days and oestrogen treatment for 2 days, in-vivo infusion of oTP into the uterine lumen for the last 3 days had no effect on oxytocin-induced PI turnover. Hixon \& Flint (1987) reported that the last 2 days of oestrogen treatment stimulated PI turnover in response to oxytocin. If oTP-1 had interfered 
with the oestrogen receptor directly, PI turnover in response to oxytocin in oTP-1 treated endometrium from ewes in Exp. 4 should have been decreased, but it was not.

We conclude that: (1) oTP-I does not affect oxytocin-induced PI turnover by endometrium in a manner which explains the antiluteolytic effect of oTP-1; (2) effects of both oTP-1 and oxytocin on inositol phosphate production in endometrium requires the presence of progesterone and the effect of oxytocin is enhanced by progesterone + subsequent oestrogen treatment while the effect of oTP1 is lost; (3) down-regulation of PI turnover is not responsible for the refractory period which occurs after oxytocin administration.

This research was supported by N.I.H. Grant HD 10436 and is published as University of Florida Agricultural Experiment Station Journal Series Number 9838. We thank Ms Glenda Walton for help with preparation of the manuscript.

\section{References}

Berridge, M.J. (1987) Inositol triphosphate and diacylglycerol: two interacting second messengers. Ann. Rev. Biochem. 56, 159-193.

Berridge, M.J., Downes, C.P. \& Hanley, M.R. (1982) Lithium amplifies agonist-dependent phosphatidylinositol response in brain and salivary glands. Biochem. J. 206, 587-595.

Fincher, K.B., Bazer, F.W., Hansen, P.J., Thatcher, W.W. \& Roberts, R.M. (1986) Proteins secreted by the sheep conceptus suppress induction of uterine prostaglandin $\mathrm{F}-2 \alpha$ release by oestradiol and oxytocin. J. Reprod. Fert. 76, 425-433.

Flint, A.P.F. \& Sheldrick, E.L. (1985) Continuous infusion of oxytocin prevents induction of uterine oxytocin receptor and block luteal regression in cyclic ewes. J. Reprod. Fert. 75, 623-631.

Flint, A.P.F. \& Sheldrick, E.L. (1986) Ovarian oxytocin and the maternal recognition of pregnancy. $J$. Reprod. Fert. 76, 831-839.

Flint, A.P.F., Leat, W.M.F., Sheldrick, E.L. \& Stewart, H.J. (1986) Stimulation of phosphoinositide hydrolysis by oxytocin and the mechanism by which oxytocin controls prostaglandin synthesis in the ovine endometria. Biochem. J. 237, 797-805.

Godkin, J.D., Bazer, F.W., Moffatt, J., Sessions, F. \& Roberts, R.M. (I982) Purification and properties of a major, low molecular weight protein released by the trophoblast of sheep blastocysts at Day 31-21. J. Reprod. Fert. 65, 141-150.

Hixon, J.E. \& Flint, A.P.F. (1987) Effects of a luteolytic dose of oestradiol benzoate on uterine oxytocin receptor concentrations, phosphoinositide turnover and prostaglandin F-2 $\alpha$ secretion in sheep. J. Reprod. Fert. 79, 457-467.

Homanics, G.E. \& Silvia, W.J. (1988) Effects of progesterone and estradiol-17 $\beta$ on uterine secretion of prostaglandin $F_{2 a}$ in response to oxytocin in ovariectomized ewes. Biol. Reprod. 38, 804-811.
Hooper, S.B., Watkins, W.B. \& Thorburn, G.D. (1987) Oxytocin, oxytocin-associated neurophysin, and prostaglandin $F 2 \alpha$ concentrations in the utero-ovarian vein of pregnant and nonpregnant sheep. Endocrinology 119, 1-8.

McCracken, J. (1980) Hormone receptor control of prostaglandin F $\alpha$ secretion by the ovine uterus. $A d v$. Prost. Thromb. Res. 8, 1329-1344.

Miller, B.G., Moore, N.W., Murphy, L. \& Stone, G.M. (1977) Early pregnancy in the ewe: effects of oestradiol and progesterone on uterine metabolism and on embryo survival. Aust. J. biol. Sci. 30, 279-288.

Roberts, J.S., Barcikowski, B., Wilson, L., Skarnes, R.C. \& McCracken, J.A. (1975) Hormonal and related factors affecting the release of prostaglandin $F 2 \alpha$ from the uterus. J. Steroid Biochem. 6, 1091-1097.

Roberts, J.S., McCracken, J.A., Gavagan, J.E. \& Solofi, M.S. (1976) Oxytocin-stimulated release of prostaglandin $F 2 \alpha$ from ovine endometrium in vitro: correlation with estrous cycle and oxytocin-receptor binding. Endocrinology 99, 1107-1114.

Sheldrick, E.L. \& Flint, A.P.F. (1986) Transient uterine refractoriness after oxytocin administration in ewes. J. Reprod. Fert. 77, 523-529.

Sheldrick, E.L., Mitchell, M.D. \& Flint, A.P.F. (1980) Delayed luteal regression in ewes immunized against oxytocin. J. Reprod. Fert. 59, 37-42.

Vallet, J.L., Bazer, F.W. \& Roberts, R.M. (1987) The effect of ovine trophoblast protein-one on endometrium protein secretions and cyclic nucleotides. Biol. Reprod. 37, 1307-1316.

Vallet, J.L., Bazer, F.W., Fliss, M.F.V. \& Thatcher, W.W. (1988) Effect of ovine conceptus secretory proteins and purified ovine trophoblast protein-1 on interoestrous interval and plasma concentrations of prostaglandins F-2 $\alpha$ and $E$ and of 13,14-dihydro-15keto prostaglandin F-2 $\alpha$ in cyclic ewes. J. Reprod. Fert. 84, 493-504. 